\title{
Adapting Dynamically to Change in Diplomacy: A Comparative Look at Special Envoys in the International Arena
}

\author{
Francesco Morini
}

Department of European Studies, Faculty of Arts and Social Sciences, Maastricht University, 6211 SZ Maastricht, the Netherlands f.morini@maastrichtuniversity.nl

Received: 5 March 2018; revised: 27 June 2018; accepted: 17 August 2018

\section{Summary}

This article provides a comparative overview of the main features of special envoys/ representatives dispatched by major foreign-policy players. It underlines the relevance of this instrument within a fast-changing diplomatic environment, characterized by increasingly numerous actors, evolving practices and complex processes that require a flexible approach. The analysis draws on nearly 650 cases of special envoys appointed by national administrations and international organizations over the span of 25 years, exposing commonalities and differences in the use of a long-standing diplomatic tool. The article argues that the incremental employment of ad-hoc envoys, mandated to deal with issues of a geographical or thematic nature, signals the ambition of individual actors to achieve specific policy objectives on a crowded global stage. In this perspective, and in keeping with their role of precursors in diplomatic practice, special envoys constitute a versatile resource with boundless potential in terms of adaptation to an ever-expanding diplomatic agenda.

\section{Keywords}

envoys - representatives - foreign-policy structures - United Nations $\mathrm{P}_{5}$ - international and regional organizations 


\section{Introduction}

Defining contemporary diplomacy is not a straightforward exercise. The diplomatic milieu has undergone more crucial developments in the last two decades than over past centuries, acquiring increasing variety and complexity in terms of agendas, actors, methods and processes. Various scholars argue that an analysis of the current state of affairs cannot disregard the essential 'duality' of diplomacy - namely, its inherent tension between inclination to continuity and quest for innovation. ${ }^{1}$ Thus, looking at recurring patterns of behaviour in foreign policy from an evolutionary perspective may help in better comprehending the condition of hybridity that characterizes diplomacy nowadays. ${ }^{2}$

Against this background, the increasing employment of 'special envoys/ representatives' (under prevailing categorizations) represents a distinctive feature of the changing diplomatic environment. Scholars and experts have recognized this and have provided a number of valuable case studies of special envoys, appointed either by national administrations ${ }^{3}$ or international and regional organizations. ${ }^{4}$ No comprehensive study, however, has been conducted to situate the role of special envoys within the constellation of foreign-policy interactions at the global level. Based on analysis of nearly 650 individual cases, this is the first contribution that offers a descriptive comparative overview of the manifold types of special envoys involved in international politics.

1 See, for example, Christer Jönsson and Robert Langhorne (eds), Diplomacy. Volume III: Problems and Issues in Contemporary Diplomacy (London: SAG E Publications, 2004); Andrew F. Cooper, Jorge Heine and Ramesh Thakur (eds), The Oxford Handbook of Modern Diplomacy (Oxford: Oxford University Press, 2013), p. 35; and Raymond Cohen, 'Diplomacy Through the Ages', in Pauline Kerr and Geoffrey Wiseman (eds), Diplomacy in a Globalizing World: Theories and Practices (New York, NY: Oxford University Press, 2013), pp. 15-31.

2 Brian Hocking and Jan Melissen, Diplomacy in the Digital Age, Clingendael Report (July 2015).

3 See, among others, Henry Wriston, 'The Special Envoy', Foreign Affairs, vol. 38. no. 2 (1960), pp. 219-237; Zhiqun Zhu, China's New Diplomacy: Rationale, Strategies and Significance (Farnham: Ashgate, 2013).

4 Giovanni Grevi, Pioneering Foreign Policy: The EU Special Representatives, Chaillot Paper no. 106 (Paris: European Union Institute for Security Studies, 2007); Cornelius Adebahr, Learning and Change in European Foreign Policy: The Case of the EU Special Representatives (Baden-Baden: Nomos, 2009); Dominik Tolksdorf, 'Diplomacy at the Individual Level: The Role of EU Special Representatives in European Foreign Policy', in Joachim Koops and Gjovalin Macaj (eds), The European Union as a Diplomatic Actor (London: Palgrave Macmillan, 2015); Connie Peck, 'Special Representatives of the Secretary General', in David Malone (ed.), The UN Security Council: From the Cold War to the 21st Century (Boulder, CO, and London: Lynne Rienner, 2004), pp. 325-339; Cyrus Vance and David Hamburg, Pathfinders for Peace: A Report to the UN Secretary-General on the Role of Special Representatives and Personal Envoys (Washington DC: Carnegie Commission on Preventing Deadly Conflict, 1997). 
The article claims that the principal value-added of these envoys is flexibility. Their titles, profiles, mandate timeframes and responsibilities are tailormade by the sending entity on the basis of particular practices, preferences and requirements. This includes the envoys' relationship with their respective structures and bureaucracies - in particular, foreign ministries at the national level - with diverse power configurations and administrative cultures playing a significant role. Besides versatility, envoys benefit from high suitability because of their 'special' status, which emanates directly from their political masters. This facilitates full acceptance by and enhances the envoys' clout vis-à-vis their counterparts.

In practice, hardly any international actor has refrained from dispatching such emissaries to pursue disparate policy objectives. Nowadays, most national administrations and multilateral organizations appoint envoys as a means to declare interest in a subject or as their commitment to remain involved on specific situations - in other words, to ensure sustained engagement and visibility vis-à-vis their external and domestic constituencies. The resulting imitation pattern leads to several groups of special envoys operating in the same crowded landscape, where logics of coordination and competition are combined to various degrees. Consistent with the concept of 'Integrative Diplomacy' developed by Brian Hocking and other scholars, ${ }^{5}$ special envoys embrace elements of change and continuity in the contemporary diplomatic environment, where primordial tasks of diplomacy remain relevant amid shifting paradigms. In this sense, they contribute to addressing effectively the rising demand for diplomacy worldwide. ${ }^{6}$

The first section of this article seeks to identify key conceptual and operational dimensions of the 'special envoy' instrument, drawing on the literature on contemporary diplomacy and recent observed cases. Hence, it moves to illustrating individual patterns of action and describing overall trends from the experience of major world powers - for this purpose, the five permanent members of the United Nations Security Council $\left(\mathrm{P}_{5}\right)$ - and the principal international and regional organizations active in conflict prevention, mediation and peace-building since the post-Cold War era, namely over the 1992-2017 timespan. In terms of methodology, the constant temporal variable enables us to recognize and measure variations in the use of special envoys. Further

5 Brian Hocking, Jan Melissen, Shaun Riordan and Paul Sharp, 'Integrative Diplomacy in the 21st Century', China International Strategy Review, 2013 (Beijing: Foreign Languages University Press, 2013).

6 Paul Sharp, Diplomatic Theory of International Relations (New York, NY: Cambridge University Press, 2009). 
analytical findings, based on an aggregated examination of the empirical material, are presented throughout different sections of the article.

\section{The Changing Nature of Diplomacy and the Role of Special Envoys}

For decades, scholars have engaged in defining the term 'diplomacy', which is commonly described as the ensemble of relations between agents of sovereign entities in terms of communication, negotiation, representation and information-gathering processes. ${ }^{7}$ The end of the Cold War revived interest among the academic community in the role of diplomacy, notably focusing on its transforming mechanisms and interactions. Following from earlier scholarly research, ${ }^{8}$ contemporary authors suggest that — rather than dwelling upon classical distinctions between 'old' and 'new' diplomacy - diplomacy should be analysed as a dynamic body subject to constant change and requiring adaptability to a complex environment. ${ }^{9}$ The qualitative and quantitative transformations of the international system between the twentieth and twenty-first century visibly brought about crucial elements of metamorphosis in diplomacy. The inter-war period first saw diplomatic patterns based on a state-centric paradigm being supplemented by an increasing multilateral dimension, in which international and regional organizations came to play a greater role. This process led to a 'polylateral',10 'multi-stakeholder'll or 'globalized'12 framework, characterized by a fluid set of diplomatic actors, norms and practices (see Table 1).

7 Harold Nicolson, Diplomacy (London: Oxford University Press, 1963); John Burton, Systems, States, Diplomacy and Rules (Cambridge: Cambridge University Press, 1968); Hedley Bull, The Anarchical Society: A Study of Order in World Politics (London: Macmillan, 1977); and Adam Watson, Diplomacy: The Dialogue Between States (London: Methuen, 1982). For instance, Harold Nicolson, 'Diplomacy Then and Now', Foreign Affairs, vol. 40, no. 1, October 1961; and Sasson Sofer, 'Old and New Diplomacy: A Debate Revisited', Review of International Studies, vol. 14, no. 3 (1988), pp. 195-211.

9 Ronald Barston, Modern Diplomacy (London: Longman, $2^{\text {nd }}$ edition 1996); Brian Hocking, 'The End(s) of Diplomacy', International Journal, vol. 53, no. 1 (1997), pp. 169-172; Brian Hocking, 'Catalytic Diplomacy: Beyond "Newness" and "Decline", in Jan Melissen (ed.), Innovation in Diplomatic Practice (London: Macmillan, 1999), pp. 21-42; and Shaun Riordan, The New Diplomacy (Cambridge: Polity Press, 2003).

10 Geoffrey Wiseman, 'Polylateralism and New Modes of Global Dialogue', in Jönsson and Langhorne, Diplomacy, pp. 36-57.

11 Brian Hocking, 'Multistakeholder Diplomacy: Forms, Functions, and Frustrations', in Jovan Kurbalija and Valentin Katrandjiev (eds), Multistakeholder Diplomacy: Challenges and Opportunities (Malta and Geneva: DiploFoundation, 2006). 
TABLE 1 Actors, content, norms and processes in contemporary diplomacy ${ }^{13}$

Actors National governments; inter-governmental and regional organizations; civil society; multinational corporations; de facto/unrecognized entities

Machinery National ministries; presidential administrations; inter-governmental/ supra-national bodies

Functions Representation; information-gathering and communication; management of relations; international negotiation; contribution to international order; duty of protection

Scope Traditional foreign-policy issues; public-policy issues (e.g. global governance, environment, trade, migration, health, freedom of belief, gender equality)

Modes Shuttle diplomacy; multilateral diplomacy; conference diplomacy; track-two diplomacy; celebrity diplomacy

Levels Local, domestic, national, bilateral, regional, global

Profile Official or unofficial/private; high-level or low-level

Timespan Short-term; medium-term; long-term

The present diplomatic landscape consists of numerous diverse actors and widening issue-areas that encompass different sectors of public policy beyond the traditional focus on foreign affairs. Against this background, diplomatic engagement is observed in multiple settings across various levels, from domestic to global. The growing complexity of interactions prompted the diplomatic machinery to develop new modalities and techniques, such as broadening stakeholder involvement and using additional channels and instruments.

Building on these premises, the concept of 'Integrative Diplomacy' provides a pertinent framework for investigating the state of the art in the diplomatic milieu. As intricate patterns of twenty-first century diplomacy are significantly conditioned by elements of continuity, in an interrelated combination of pre-modern, modern and post-modern features, the integrative approach upholds the need to reconcile shifting paradigms in the different dimensions of diplomatic activity. ${ }^{14}$ In essence, as the traditional boundaries of diplomacy become blurred, adaptation to and management of change must occur at multiple levels. Diplomatic actors are thus required to possess specific traits that

13 Adapted from Cooper et al., The Oxford Handbook of Modern Diplomacy, p. 6; Barston, Modern Diplomacy, p. 2; and Geoffrey Berridge, Diplomacy: Theory and Practice (Basingstoke: Palgrave Macmillan, 3rd edition 2005), pp. 242-250.

14 Hocking et al., 'Integrative Diplomacy in the 21st Century'. 
enable them to master an environment characterized by increasing specialization, enhanced interdependencies and changing demands. All-round players capable of 'connecting the dots' and managing policy networks are indispensable, acting at once as linkage points within broader diplomatic structures and as external boundary-spanners.

Within this context, the evolving role of 'special envoys' - in Geoffrey Berridge's words, 'persons sent abroad to conduct diplomacy with a limited purpose for a limited time' 15 - in the diplomatic practice of state and nonstate actors alike appears particularly relevant. This notion derives from the convention to dispatch ad-hoc legations to alien political jurisdictions, documented since the ancient Egyptian, Greek and Roman civilizations. The first envoys were tasked by their rulers to conduct short-term missions and perform manifold diplomatic duties - namely, representation, negotiation, mediation and information exchange. ${ }^{16}$ While this bundle of proto-diplomatic practices essentially defined certain basic functions of the 'modern' diplomat, emerging priorities in international relations favoured the gradual establishment of the resident ambassadorship. Resident ambassadors became the customary form of diplomatic representation in the post-Westphalian order, dominated by sovereign political actors. Despite the major political transformations that have occurred since, the resort to special emissaries has nonetheless remained a universal practice of foreign-policy actors, notably states. ${ }^{17}$ A prime example was the almost simultaneous appointment of 'personal representatives' (sherpas) by all $\mathrm{G}_{7}$ countries in the mid-1970s, with specific tasks to carry out preparations for the informal summits of heads of state and government. Such arrangements have consolidated over time, alongside the general trend towards summitry and the increased importance of economic diplomacy worldwide.

The basic dimensions throughout which special envoys operate have significantly evolved. While the management of short-term issues represents a key function of diplomacy, the temporal scope of envoys' activities has gradually encompassed longer-term assignments, mainly to ensure continued engagement with stakeholders. Among further dichotomies identified in the

15 Geoffrey Berridge, Talking to the Enemy: How States without 'Diplomatic Relations' Communicate (Basingstoke: Macmillan, 1994), pp. 113-116.

16 Cooper et al., The Oxford Handbook of Modern Diplomacy; and Keith Hamilton and Richard Langhorne, The Practice of Diplomacy: Its Evolution, Theory, and Administration (London: Routledge, 2nd edition 2011), pp. 7-31.

Wriston, 'The Special Envoy', p. 219. 
literature, ${ }^{18}$ the one between official and unofficial emissaries is mostly relevant for contemporary diplomacy, because of the growing relevance of non-state entities in foreign policy and the need to utilize informal channels of communication in politically sensitive contexts. The transformation of the international environment emphasized two additional dimensions: the envoy's profile and background, which may range from politicians to bureaucrats and professionals with specialist competence on given subject matters; and the scope of the envoy's action, which came to address thematic or horizontal issues alongside the traditional geographical focus on specific countries or regions. In parallel, special emissaries once bearing titles of 'agent', 'delegate' and 'commissioner' began to be referred to as 'envoy', 'representative', 'adviser', 'coordinator', or occasionally 'ambassador-at-large'. In practice, such designations are interchangeable and follow generally established patterns. The diagram below (see Fig. 1) conceptualizes the potential extent of special envoys' appointments and the countless configurations offered by this instrument.

The four above-mentioned dimensions - character, mandate timeframe, profile and remit - characterize the vast majority of international envoys. Two recent initiatives of the Canadian government are illustrative in this respect, as they combine fundamentally opposite features. In May 2017, Canada's Prime Minister Justin Trudeau officially appointed a prominent political figure to combine two asymmetric assignments of a long-term nature and with a

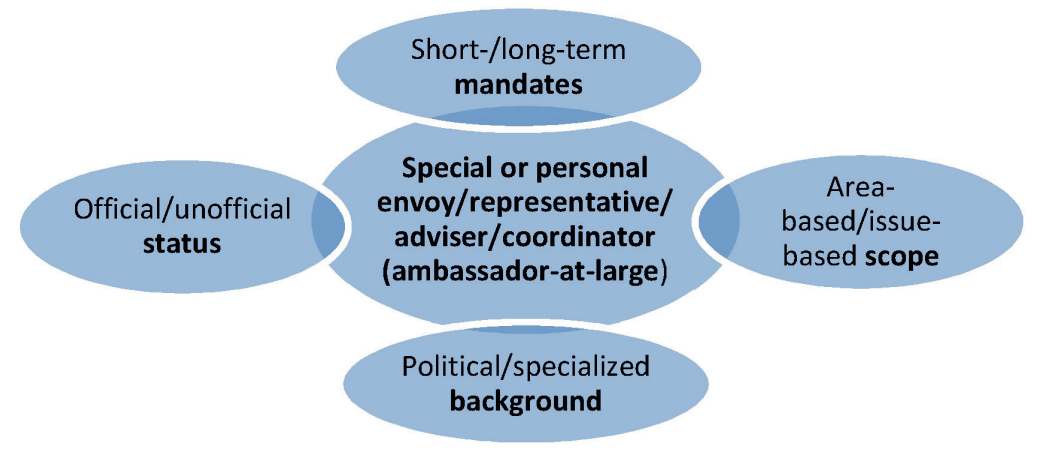

FIGURE 1 Dimensions of ad-hoc envoys: character, mandate timeframe, profile and remit

18 Berridge, Talking to the Enemy, p. 113 . 
geographical remit - namely, those of resident ambassador to Germany and special envoy 'to the European Union and Europe'. Interestingly, this unique designation intervened after a three-month hiatus from an earlier official communication, which had announced a 'dual resident ambassadorship' to both Berlin and Brussels for the same individual, ${ }^{19}$ but in effect left most European partners perplexed. Shortly thereafter, North Korean media reported about the unannounced visit of a 'special envoy' sent by the Canadian prime minister, allegedly vested with the specific mission of obtaining the swift release of a Korean-Canadian pastor long detained by Pyongyang's regime and sentenced to life imprisonment. Unsurprisingly, the high political sensitivity of the assignment made the employment of an unofficial envoy with specialized security background particularly suitable.

While these cases exemplify the potential constellations in which special envoys can operate, a more extensive comparative study should unveil additional features and trends pertaining to the activities of special envoys. The following section will therefore examine figures, processes and dynamics originating from the diplomatic practices of the $\mathrm{P}_{5}$, before turning to the experience of major international and regional organizations.

\section{Special Envoys of Major State Actors}

\section{United States}

In the United States (US), appointments of special envoys traditionally pertain to the President. ${ }^{20}$ Starting from the 1960 , this mainly applied to ad-hoc US representation on international trade negotiations, ${ }^{21}$ as well as off-therecord contacts with unrecognized entities and hostile countries, ${ }^{22}$ as official engagement with those was seen reluctantly. Through the latter dimension, a distinctive character of 'personal diplomacy' emerged, reflecting the growing

19 Press releases of 1 May 2017 (http://pm.gc.ca/eng/news/2017/05/o1/prime-minister-an nounces-appointment-honourable-stephane-dion-ambassador-germany-and); 31 January 2017 (http://pm.gc.ca/eng/news/2017/01/31/prime-minister-puts-forward-honourablestephane-dion-ambassador-european-union-and). While the special envoy would operate within the same political space as Canada's full-time ambassador to the EU, his mandate seemingly conferred on him horizontal responsibilities to coordinate the activities of Canadian diplomatic missions across Europe and address overarching policy issues relevant to Canada and the EU globally. Michael Fullilove, 'All the Presidents' Men: The Role of Special Envoys in US Foreign Policy', Foreign Affairs, vol. 84, no. 2, (2005) pp. 13-18.

21 See online at https://1997-2001.state.gov/www/about_state/history/officers/ustr.html. Berridge, Diplomacy, pp. 242-250; and Barston, Modern Diplomacy, p. 74. 
involvement of heads of state or government in foreign policy. The White House made extensive use of such 'personal' or 'private' envoys, whether with an official or unofficial status and varying profiles, to act upon a direct presidential mandate (and non-compulsory authorization by the US Congress) as fact-finders or troubleshooters on specific situations. ${ }^{23}$

During the 1990s, multiple threats to international peace and security increased the conflict-related focus of US special envoys. Presidents and secretaries of state resorted more regularly to such appointments upon the emergence of crises that prompted congressional and public attention - and, often, expectations from the conflicting parties themselves. Under Bill Clinton's successive presidencies (1993-2001), the overall number of the pool of 'Special Envoys, Representatives, Advisers and Coordinators' (also including a handful of 'Ambassadors-at-Large') expanded three-fold; in terms of geographical distribution, the African continent received privileged attention because of the acute conflicts and political crises marring several sub-Saharan countries. ${ }^{24}$ During George W. Bush's two consecutive stints as president (2001-2009), marked by the multiplication of new conflict hotspots in the Middle East and Asia, the increment of special emissaries was relatively contained. Towards the end of Bush's second term, the US State Department's official records listed around 25 such positions. ${ }^{25}$

Marking a deviation from the moderate trend observed in other countries, the exponential rise in appointments registered during US President Barack Obama's administration (2009-2017) resulted in 70 special emissaries existing at the time of the presidential transition between November 2016 and January $2017 .{ }^{26}$ Despite significant differences in the mandates and responsibilities of each envoy, this development explained the White House's intent to project its diplomatic style and policy priorities by dispatching ad-hoc agents often situated outside the standard bureaucratic lines of the US State Department. Important cross-cutting issues, such as climate-change negotiations or outreach to the Islamic community, gradually gained predominance on matters pertaining to conflict-related situations. ${ }^{27}$ In parallel, profiles of technical

\footnotetext{
23 Berridge, Talking to the Enemy, pp. 113-116.

24 See online at https://1997-2001.state.gov/www/about_state/biography/index.html.

25 See online at https://2001-2009.state.gov/r/pa/ei/biog/c7647.htm.

26 US Department of State, 'Alphabetical List of Bureaus and Offices: Other Senior Officials', available online at http://www.state.gov/r/pa/ei/rls/dos/1718.htm (consulted on 1 October 2016 and 1 September 2017).

27 John Naland, 'US Special Envoys: A Flexible Tool', Peace Brief no. 102 (Washington, DC: US Institute for Peace, August 2011); Princeton Lyman and Robert Beecroft, 'Using Special
} 
experts, military leaders and politicians started to feature more regularly alongside the typical 'diplomatic' envoy.

Unlike previous transitions, US President Donald Trump's administration seemed to herald the beginning of a reverse process, not only relating to the foreseeable phasing-out of certain positions to signal shifting policy priorities, but also addressing repeated calls for rationalization of the system. As a result, the proposal unveiled by then Secretary of State Rex Tillerson between July and August 2017 presented several arguments for the radical reorganization of the existing contingent of special envoys, highlighting in particular efficiency, transparency and accountability reasons - including the constant circumvention by former presidents of congressional and governmental channels. The suggested measures would massively reduce the number of 'full-fledged' special representatives, with up to 36 positions to be eliminated or folded back into other bureaus within the State Department. ${ }^{28}$

This rearrangement connotes the potential downsides of a 'proliferation' of ad-hoc emissaries. Besides diluting the core objective of drawing attention to certain subject matters, an excessive reliance on these functions may engender divisive turf battles between foreign-policy structures at the national level. The trade-off between outreach and the effectiveness of special envoys appears particularly crucial in the US case. The growing number of these appointments, driven by Washington's claimed role of global superpower, has arguably contributed to the United States' constant visibility on the international scene. However, the internal legitimacy of an ever-larger pool of 'specials' is increasingly being questioned, giving rise to public disagreement. Hence, under certain circumstances, the risk exists that the special-envoy function may ultimately become devoid of substance. ${ }^{29}$

\section{United Kingdom and France}

Former colonial powers and United Nations Security Council (UNSC) permanent members, the United Kingdom (UK) and France traditionally share

Envoys in High-Stakes Conflict Diplomacy', Special Report (Washington, DC: US Institute for Peace, October 2014).

28 See the undated letter from Tillerson to Bob Corker, Chairman of the US Senate's Committee on Foreign Relations, available online at https://www.documentcloud.org/ documents/3982871-State-Letter.html; Nahal Toosi, “Tillerson Faces Fights on Eliminating Envoys', Politico, 26 July 2017; and Cory Gill and Susan Epstein, 'State Department Special Envoy, Representative, and Coordinator Positions: Background and Congressional Actions', Congressional Research Service Report R44946 (September 2017). The few Special Representatives created under Trump's administration are not addressed in the letter, as with another five existing positions.

American Academy of Diplomacy, 'American Diplomacy at Risk' (April 2015). 
similar aspirations on the global stage. Besides possessing the two largest diplomatic networks at the European level, they show converging patterns in terms of selection and appointment of ad-hoc emissaries. In line with the integrative model of diplomacy, both countries tend to tap specialized expertise and organize systematic support at the operational level by pooling different governmental structures.

Since the early 1990s, the UK foreign secretary has regularly mandated special envoys to deal with countries, areas or regions troubled by political crises or conflict. Similarly, successive UK prime ministers have also appointed their own representatives on disparate issues, not without controversy in some cases. ${ }^{30}$ Against this background, different trends have come to the fore in recent years. While most governmental envoys have historically been civil servants or military officers with specific geographical expertise, British parliamentarians are currently preferred because of their higher political stature. Furthermore, various envoys began to address thematic or horizontal issues. Innovative practices were also tested, notably through synergies between the Foreign \& Commonwealth Office (FCO) and other governmental bodies: for example, in October 2008, a Climate Envoy for Vulnerable Countries was created jointly with the Department for International Development; in November 2009, a Climate and Security Envoy was established together with the Ministry of Defence. ${ }^{31}$ Both positions were subsequently scrapped in favour of the existing FCO-mandated Special Representative for Climate Change.

The creation of an ample network of 'Trade Envoys' was, however, the most significant novelty. Intending to step up London's traditional engagement on trade-related issues ${ }^{32}$ with emerging economies, in autumn 2012 then Prime Minister David Cameron decided to appoint one 'resident' and one 'roving' trade envoy to this effect. This strategy was complemented by tasking eight parliamentarians, drawn from across the political spectrum, to promote trade for UK businesses in selected high-growth and developing markets around the world. Over the years, the number and geographical scope of action of UK Trade Envoys has grown tremendously. ${ }^{33}$ While the current network of roughly

30 For instance, the appointment of a Special Envoy for Sri Lanka was rejected outright by the local authorities; see Randeep Ramesh and Andrew Sparrow, 'Sri Lanka Accuses Britain of Meddling in Internal Affairs', The Guardian, 13 February 2009, available online at https:// www.theguardian.com/world/2009/feb/13/sri-lanka-london-diplomatic-relations. House of Commons Foreign Affairs Committee, Foreign \& Commonwealth Office Annual Report 2008-2009, HC 145 (London: The Stationery Office, 2010).

32 The position of 'Special Representative for International Trade and Investment' — held by a British Royal Family member — had existed since 1976 .

See https://www.gov.uk/government/groups/trade-envoys. 
30 emissaries is supervised by a London-based Trade Envoy Coordinator, the local UK embassies and high commissions around the world continue to provide support in the field.

Across the Channel, France had just begun setting its path in that direction. In August 2012, French Foreign Minister Laurent Fabius appointed a handful of 'Special Representatives for Economic Diplomacy' (notably for Algeria, China and Japan), with the objective to upgrade relations at the 'political, economic, commercial, scientific and cultural level' with selected countries and regional bodies worldwide. The approach was two-fold: envoys had to possess strong familiarity with and personal connections in the area concerned, which made private-sector managers well suited for the task; and in parallel, full-fledged operational support was provided by the French administration in Paris and onsite. In five years, the size and geographical scope of French economic envoys broadened considerably: currently, fourteen such figures operate across five continents. ${ }^{34}$ Lately, French and British envoys have been pursuing similar mandates in seven countries or regions (Algeria, Angola, Brazil, Canada, Mexico, South-East Asia and South Africa). As an exception to the rule, 'personal envoys' of the French President have sporadically been appointed with almost identical tasks.

On the traditional diplomatic front, France has long employed special representatives for a variety of tasks, prioritizing countries and regions of the highest political interest but occasionally appointing emissaries with a thematic remit, notably to underpin key policy initiatives..$^{35}$ Senior diplomatic officials were routinely tasked with addressing protracted or newly emerging conflict situations - such as in Afghanistan, Libya, Syria and the Sahel region frequently, with rather short mandate timeframes and strong reliance on the competent structures of the Quai d'Orsay. An illustrative case was the targeted attempt to reinvigorate the stalling Israeli-Palestinian negotiations: in early 2016, senior diplomat Pierre Vimont was appointed as Special Envoy to spearhead outreach efforts in gathering support for the 'French Initiative for a Middle East Peace Conference'. The French emissary regularly liaised with all of the relevant stakeholders at the regional and European level in the run-up to the conference, which finally took place in Paris in January 2017.

34 See online at https://www.diplomatie.gouv.fr/fr/politique-etrangere-de-la-france/diplo matie-economique-et-commerce-exterieur/soutenir-les-entreprises-francaises-a-letranger/un-plan-d-action-pour-l-ensemble-du-ministere/des-representants-speciauxdu-ministre-a-l-etranger-pour-la-diplomatie/.

35 A 'Special Envoy for the Protection of the Planet' was appointed in 2012, inter alia to help prepare for the International Conference on Climate Change (COP21) held in Paris in December 2015 . 


\section{Russia and China}

In Russia and China, the notion of special envoy seems to be strongly influenced by similar administrative practices rather than foreign-policy approaches.

During the Soviet rule, several spetsial'nye predstaviteli were instrumental in establishing high-level channels of communication to settle bilateral disputes or normalize shaky diplomatic relations. An emblematic case was the mechanism of regular consultations between Chinese and Soviet special representatives, who met a dozen times in Beijing and Moscow between 1979 and 1988 to mend tense Sino-Soviet relations. ${ }^{36}$ In October 1991, President of the Russian Soviet Federative Socialist Republic (RSFSR) Boris Yeltsin attempted to handle the complex political transitions unfolding in the practically defunct Soviet Union by mandating a special representative (serving as deputy minister) to manage relations with the former Soviet republics during the following year.

Traditionally, the president of the Russian Federation retains the prerogative to appoint envoys and define the scope of their mandates. ${ }^{37}$ While preference is given to senior career diplomats or parliamentarians on matters pertaining to the foreign-policy dimension, the sectoral nature of other assignments favours the selection of public office-holders with the required expertise, ranging from ministers to local administrators. More visibly than elsewhere, Moscow's approach embodies the evolution of the diplomatic processes as a continued fusion of domestic and foreign policy. The most illustrative case dates back to February 2000, when freshly elected Russian President Vladimir Putin appointed a 'Special Presidential Envoy responsible for human rights and freedoms in the Chechen Republic'. ${ }^{38}$ The position was maintained for the following four years and presented to the international community as Moscow's operational measure to address the deteriorating situation on the ground.

Since then, the overall number of special envoys has stabilized at fifteen to twenty on average during each presidential term, with occasional discontinuations happening throughout. These appointments delineate distinguishable policy approaches: (i) Russia's attention to its immediate neighbourhood in view of maintaining and developing economic, cultural and humanitarian

36 See online at http://www.fmprc.gov.cn/mfa_eng/ziliao_665539/3602_665543/36o4_ 665547/t18018.shtml.

37 The President also appoints 'Plenipotentiary Envoys' to the country's eight Federal Districts and to three key branches of federal power (the Federation Council, the State Duma and the Constitutional Court). Unlike the special envoys/representatives, these officials are embedded into the presidential administration and oversee the work of federal bodies or agencies on behalf of the central government.

38 See http://special.kremlin.ru/acts/bank/15187 and http://special.kremlin.ru/acts/bank/ 15827 . 
links, as well as addressing regional issues; (ii) a tendency to promote the presence of specialized experts in regional or international cooperation formats, both at the geographical and thematic level; and (iii) a focus on selected major issues of foreign policy and regions on which Moscow intends to punch its weight on the international stage.

For the latter category, the Kremlin usually favours a double-hatting arrangement to elevate the profile of its representatives, who are senior officials contemporarily holding the position of deputy/assistant minister or even minister at times. In practice, Russia may also engage with other parties' envoys by tasking high-level officials to act as their counterparts on sensitive bilateral issues, as demonstrated by the direct diplomatic channels existing between the Russian Secretary of State and the Georgian Prime Minister's Special Representative for relations with Russia since 2012, or between the Russian Presidential Representative and the US Special Representative for Ukraine Negotiations since 2017 .

After its recognition as the legitimate representative of China to the UN in 1971, the People's Republic of China (PRC) formally continued to adhere to its principle of 'non-interference' in the internal affairs of other countries. Accordingly, while the practice of dispatching ad-hoc envoys had been adopted by Beijing's government at least since 1962, it predominantly served short-term, ceremonial purposes. ${ }^{39}$ Notable exceptions were the bilateral mechanisms established respectively in the 1980 s with the Soviet Union and, in the same period, in relation to the Sino-Indian dispute on the unsettled boundary dividing the two states..$^{40}$ Regardless of the objectives pursued, appointments of special envoys gradually emerged as a presidential prerogative, albeit with an unclear role for the PRC's de facto legislative body, the National People's Congress Standing Committee. Indications of a paradigm shift in Beijing first appeared in August 1987, with the initiative to send a special envoy (tè shǐ) to Tehran in the context of the Iran-Iraq war. ${ }^{41}$ Since then, China has sought an increasingly active role in global governance as a mediator in regional and international affairs, alongside its rising economic influence. The deployment of various special envoys on selected issues became instrumental to such aspirations.

39 Zhang Runhua, The Constitutional and Legal Development of the Chinese Presidency: The Emperors' New Clothes? (Lanham, MD: Lexington Books, 2014), pp. 154-155.

40 G.V.C. Naidu, Mumin Chen and Raviprasad Narayanan (eds), India and China in the Emerging Dynamics of East Asia (New Delhi and New York NY: Springer, 2015), pp. 95-98. 
The Middle East remained an area of major diplomatic interest, with the appointment since 2002 of a 'Special Envoy for the Middle East' to contribute to the Israeli-Palestinian peace process and develop relations with relevant stakeholders. ${ }^{42}$ The unfolding Syrian crisis gave Beijing an opportunity to push its political agenda through the appointment of three dedicated special envoys with definite short-term assignments and targeted interlocutors, whose primary aim was to explain China's position in the UNSC and prepare the ground for its own diplomatic initiative. ${ }^{43}$ The coordinated action of those envoys was instrumental to upgrading China's involvement on the matter and was later remodelled into supporting the UN-led mediation efforts.

Altogether, the current pool of Chinese special envoys well synthetizes two key dimensions of the country's evolving foreign policy approach: (i) a truly comprehensive geographical outreach, with a chief interest on the African continent and the developments around the Korean peninsula, recently integrated by officials in charge of Asian and Latin American affairs, respectively; and (ii) a growing involvement on thematic/horizontal issues, indicated inter alia by the appointment of a 'Special Representative for Human Rights', who conducts regular dialogues and consultations with selected countries and regional blocs. In conclusion, we see that out of eleven envoys currently operating, five also hold Deputy/Assistant Minister positions, thereby strongly anchoring their activities in the overarching foreign-policy structure while acting as its flexible extensions.

\section{Special Envoys of International and Regional Organizations (see Fig. 2)}

\section{United Nations}

While the UN Charter's provisions do not explicitly foresee the possibility of deploying ad-hoc envoys, the UNSC and the United Nations General Assembly (UNGA) soon resorted to this instrument in order to address conflict situations unfolding on the Indian continent, the Korean Peninsula and the Middle East. In 1948, Folke Bernadotte was appointed as UN 'Mediator' in Palestine to use his good offices for a peaceful settlement of the dispute and provide regular reporting to New York. ${ }^{44}$ The profile of UN-mandated mediators has followed

\footnotetext{
42 Zhu, China's New Diplomacy, p. 69.

43 Muhamad Olimat, China and the Middle East: From Silk Road to Arab Spring (Abingdon; Oxon: Routledge, 2012).

44 UNGA Resolution no. 186 (1948).
} 


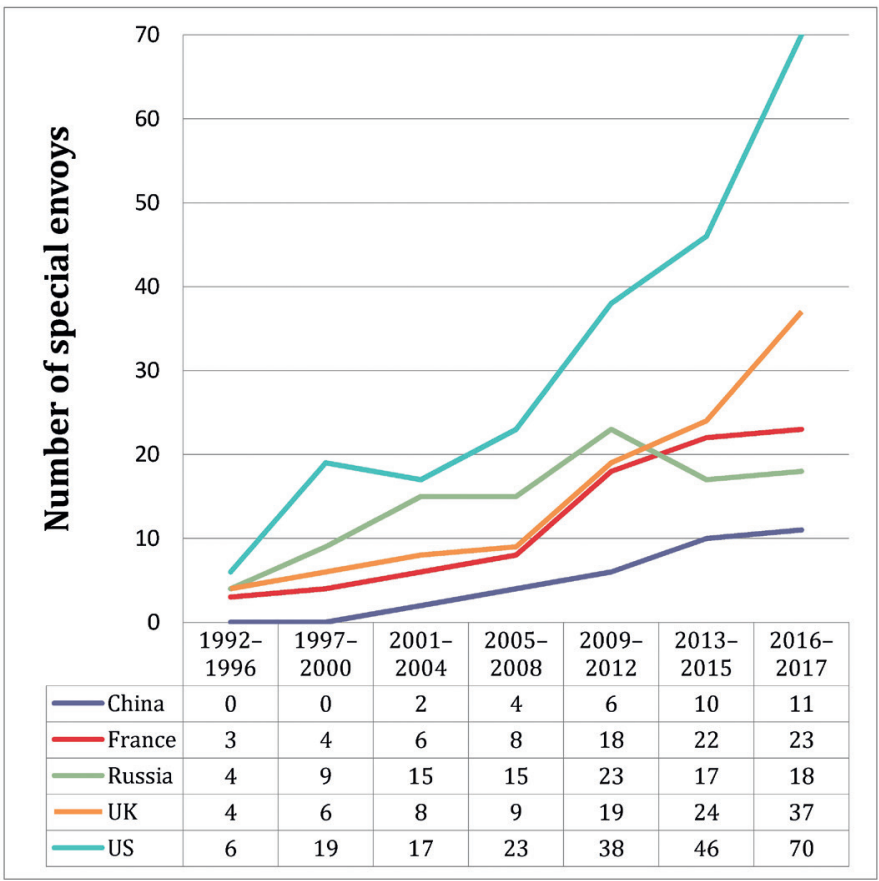

FIGURE $2 \quad P_{5}$ special envoys and representatives 1992-2017 (evolution by period)

distinctive lines since, as several experienced diplomats have been deployed to manage delicate inter-state and intra-state disputes. The duties and responsibilities pertaining to the United Nations Secretary-General (UNSG) under articles 98, 99 and 101 of the UN Charter served as indirect legal foundations to legitimize the activities of these emissaries. ${ }^{45}$ Hence, the UNSG's supervision and authority over the vast category of 'Special and Personal Representatives, Envoys and Advisers of the Secretary-General' is not disputed, although broader institutional dynamics between UN bodies often come into play in such appointments.

The deployment of 'personal' or 'special' representatives engaged in mediation and deal-brokering efforts on behalf of the UNSG remained at the core of the UN's activities in conflict resolution for decades, albeit with contained figures (no more than ten such envoys operated during the 1980s). Major changes occurred under the successive leaderships of UNSG Boutros Boutros-Ghali and UNSG Kofi Annan, who designated numerous special envoys to handle

45 Thomas Franck, 'The Secretary-General's Role in Conflict Resolution: Past, Present and Pure Conjecture', European Journal of International Law, vol. 6, no. 3 (1995), pp. 360-387. 
challenging political crises and threats to international security. In quantitative terms, numbers have risen steadily to the current number of nearly $70 \mathrm{UN}$ emissaries. While a majority of these positions still relate to crisis management and mediation, increasing attention towards thematic and horizontal issues has emerged since Ban Ki-Moon's tenure as UNSG. Currently accounting for about 40 per cent of the current UN contingent of 'specials', issue-oriented envoys are usually eminent personalities with political or specialized backgrounds, whose appointments signal the organization's intention of stepping up its engagement and outreach efforts on global themes.

In parallel, the multifaceted dimensions of UN engagement on a world scale have made the widening of envoys' roles and mandates crucial. Since the early 199os, UN envoys have assumed broader management, representation, coordination and advisory duties. Principally, they head UN field missions or political missions and act as leading mediators in diplomatic peace processes, but can also undertake special missions on behalf of the Secretary-General and engage in various forms of preventive and shuttle diplomacy. Thus, the variety of circumstances in which special envoys have been utilized seems to have gradually blurred the traditional distinction dividing conciliation, good offices and mediation at the UN level.

The UNSG maintains ample flexibility in defining the mandates and bases of operations of UN emissaries. The assignment of respective titles largely draws on the customary designations of Special/Personal Representative, Envoy, Adviser or Coordinator. ${ }^{46}$ Amongst these categories, the so-called 'Special Representatives of the Secretary-General' (SRSG) stand out as true 'diplo-managers'. As double-hatted chiefs of the UN multi-dimensional or political missions deployed in the field, they not only ensure overall coordination of the UN system in a given country and/or region, but can also play a catalyst role vis-àvis other international actors such as regional or sub-regional organizations. ${ }^{47}$

A widespread notion that has lately emerged in several UN bodies namely, the United Nations Educational, Scientific and Cultural Organization (Unesco), the United Nations Children's Fund (Unicef) and the United Nations High Commissioner for Refugees (UNHCR) - is 'celebrity diplomacy'. 48 The regular appointment of special envoys for visibility and advocacy purposes is part of this phenomenon, which denotes the changing forms and methods

46 UN Joint Inspection Unit, "Transparency in the Selection and Appointment of Senior Managers in the United Nations Secretariat' (2011), pp. 5-7.

47 John Karlsrud, 'Special Representatives of the Secretary-General as Norm Arbitrators?', Global Governance, vol. 19, no. 4 (2013), pp. 525-544.

48 Andrew Cooper, Celebrity Diplomacy (Boulder, CO: Paradigm Publishers, 2008). 
of conducting diplomacy. On the operational side, distinguished personalities in disparate fields benefit greatly from the formal institutional linkages with UN agencies to gain legitimacy vis-à-vis external interlocutors, in addition to their recognized prestige at the global level. Despite the criticism expressed by certain observers, this practice can usefully supplement traditional approaches to diplomacy and enjoys ample flexibility, as demonstrated by the unclear boundaries between the categories of 'goodwill ambassadors' and properly defined 'special representatives'. ${ }^{49}$ However, political considerations have occasionally altered this paradigm, such as with the selection of qualified experts as the UNICEF Special Representatives in charge of Palestine or Libya, respectively. Similarly, the UNHCR's involvement in the context of massive migratory and refugee flows prompted the appointment of special envoys dealing respectively with the Somali refugee situation and the Central Mediterranean situation. ${ }^{50}$

\section{$\operatorname{OsCE}$}

In the framework of the Organization for Security and Cooperation in Europe (OSCE), the possibility to deploy ad-hoc envoys on specific areas or issues originates from collective decisions taken by the OSCE's participating states at the beginning of the 1990s. The authority to designate emissaries belongs to the Chairman-in-Office ( $\mathrm{CiO}$ ), an annually rotating position held by one of the participating states' foreign minister. As spelled out in the documents agreed at the 'Helsinki II' and Budapest summits, ${ }^{51}$ the leading position of the $\mathrm{CiO}$ in the domain of conflict prevention, management and resolution in the OSCE region could be supported by the activities of 'personal representatives with a clear and precise mandate', dispatched to deal with crisis situations as appropriate. In the 'early years' of the OSCE's activity (1992-1997), this tool was used to attain specific objectives amid shifting priorities. Initially tasked to facilitate the establishment of an OSCE presence in newly joining countries and to devise regional strategies, personal/special representatives became increasingly

49 Angelina Jolie was UNHCR Goodwill Ambassador before becoming Special Envoy in April 2012. UNESCO distinguishes between Special Envoys (http://www.unesco.org/new/en/ goodwill-ambassadors/special-envoys/) and Goodwill Ambassadors. UnICEF lists several 'Goodwill Ambassadors and Advocates', but no Special Representatives (https://www .unicef.org/people/people_ambassadors_international.html).

The Council of Europe made an analogous step by appointing a 'Special Representative on Migration and Refugees' in January 2016 (https://www.coe.int/en/web/specialrepresentative-secretary-general-migration-refugees/home).

51 CSCE Helsinki Document, 1992 (http://www.osce.org/mc/39530?download=true); CSCE Budapest Document, 1994 (https://www.osce.org/mc/39554?download=true). 
involved in OSCE-led conflict-settlement processes and the resolution of acute political crisis in the OSCE area. Depending on the expertise required, envoys were typically drawn from the diplomatic or military milieu.

Altogether, despite occasional difficulties and shortcomings, these experiences sustained the Chairman-in-Office's pivotal role in preventing and managing conflicts in the OSCE area - including a greater focus on mediation through the conduct of various conflict settlement negotiations. The closer coordination that was developed within the OSCE 'troika' led to several cases of reappointments, or joint arrangements that allowed the designation of Special Representatives with mandates exceeding the theoretical one-year assignment. The creation of thematic envoys, which sought to demonstrate the engagement of OSCE participating states on horizontal topics of general relevance, followed a similar pattern: between 2004 and 2005, five such functions were created, focusing respectively on different aspects of the fight against intolerance and discrimination, combating trafficking in human beings, as well as gender issues. ${ }^{52}$

While reconfirmations of Personal and Special Representatives have become a recurring feature in the OSCE system, each Chairmanship-in-Office retains the prerogative to determine the scope of its emissaries' mandate, as illustrated by the succession of those dealing with the so-called 'protracted conflicts' in the OSCE area. Previously regrouped under the responsibility of a single envoy, the mandates related to each conflict have remained separate under recent chairmanships, somehow mirroring existing different negotiation formats and mechanisms. ${ }^{53}$ Similarly, in 2014 a dedicated envoy was appointed to represent the Chairman-in-Office in the 'Trilateral Contact Group', a format designed to find solutions to the conflict in eastern Ukraine. ${ }^{54}$

Building on these precedents, another category of special representatives has emerged in the OSCE context over recent years. The organization's Parliamentary Assembly (PA), composed of 323 lawmakers from all OSCE participating states, regularly entrusts its individual members with mandates on regional and cross-cutting thematic issues, some of which happen to overlap with areas or subjects covered by the Chairman-in-Office's envoys. In numerous cases, the OSCE PA's Special Representatives take a pivotal role in

$5^{2}$ The mandates of the two existing NATO Special Representatives partly overlap with those of OSCE envoys: in 2012, NATO's Secretary-General appointed a 'Special Representative for Women, Peace and Security', followed by a 'Special Representative for the Caucasus and Central Asia' two years later.

53 The Transdniestrian Settlement Process or ' 5 +2'; the Geneva International Discussions on the 2008 conflict in Georgia; and the Nagorno-Karabakh conflict.

54 See http://www.osce.org/cio/representatives. 
coordinating and leading the official visits of the PA's delegations to areas of concern or crisis. ${ }^{55}$

\section{European Union}

While the Council of the European Union in 1996 appointed its first special envoys on the African Great Lakes region ${ }^{56}$ and the Middle East Peace Process ${ }^{57}$ respectively, precursors existed even before the Common Foreign and Security Policy (CFSP) was integrated into the institutional architecture configured by the Maastricht Treaty. Between 1991 and 1993, the member states of the European Community had mandated 'special emissaries' to lead joint mediation efforts in seeking a solution to the Yugoslav crisis. The combination of a relatively light legal and institutional framework and urgent political issues on the EU's international agenda pushed the boundaries of the special envoys' action and led to a gradual expansion of their geographical and topical remit. In the first decade of the CFSP's formal existence (1993-2003), thirteen special emissaries were appointed by the Council, with roughly half of them operating in the crisis-affected Western Balkans region. This well-established practice had meanwhile been formalized in the Amsterdam Treaty, which introduced the notion of EU Special Representatives (EUSRs) mandated by the Council 'in relation to particular policy issues'.

The succinct legal basis for the appointment of EUsRs has since remained practically unaltered, including in the Lisbon Treaty. The readjustments that occurred within the CFSP's institutional architecture had an impact on the operational dimension instead: ${ }^{58}$ the tasks of EU envoys were adapted and widened, in line with similar processes unfolding in the UN and OsCE. Traditionally characterized as the 'eyes and ears' of the EU because of their privileged position in information-gathering, in the post-Lisbon configuration EUSRs share this function with country-resident Heads of EU Delegations, while retaining a distinguishable role in terms of visibility. Additionally, the reorganization of the EU's civilian and military crisis-management structures and the multiplication of instruments available in the Union's foreign-policy 'toolbox' led EUsRs to become integral components of the EU's 'joined-up' approach, rather than to act as principal coordinators in the field. Overall, these trends signal a shift from single-country appointments towards regional and

55 See https://www.oscepa.org/about-osce-pa/special-representatives.

56 Joint Action of 25 March 1996 (96/250/CFSP).

57 Joint Action of 25 November 1996 ( $96 / 675 /$ CFSP).

$5^{8}$ Dominik Tolksdorf, 'EU Special Representatives: An Intergovernmental Tool in the Post-Lisbon Foreign Policy System?', European Foreign Affairs Review, vol. 4, no. 1 (2013), pp. 471-486. 
thematic ones. Of the eight current EUSRs, half cover geographical regions, while the two serving in the Western Balkans remain the residual examples of the double-hatting arrangement coupling the functions of the EUSR and Head of the local EU Delegation/Office. ${ }^{59}$

Besides, the constellation of around 25 other ad-hoc envoys and representatives deployed alongside EUSRS outside the legal provisions of the EU treaties should not be omitted. Former EU High Representative for CFSP Javier Solana regularly appointed 'personal envoys', entrusted with responsibilities of a geographical or thematic nature and varying mandate timeframes. Their tasks were in certain cases redefined under subsequent institutional or policyrelated developments, which led for instance to the creation of a EUSR for Human Rights in July 2012. Since the establishment of the European External Action Service, successive High Representatives/Vice-Presidents (HR/VPs) have appointed (special) coordinators, advisers, envoys and ambassadors-atlarge, formally embedded in the structure. These officials adopted tasks that once pertained to EUSRs or were given responsibilities for cross-cutting issues and specific international processes.

Other EU institutions have followed suit: the European Council in 2015 and the European Commission in 2016 availed themselves of the contribution of personal/special envoys to attain short- or medium-term policy objectives. Out of almost 75 special emissaries appointed over 25 years of CFSP, the vast majority have engaged in crisis and war-affected areas, showing the EU's privileged interest in preventive diplomacy, conflict resolution and mediation.

\section{The African Union and Sub-regional Organizations}

Inspired by the experiences of other multilateral actors, the African Union (AU)'s growing involvement in the field of mediation has resulted to date in the deployment of approximately twenty special envoys, representatives and mediators to address conflict-related situations across the African continent. Based on the statutory provisions contained in the AU Peace and Security Council (PSC) Protocol, appointments are made by the bodies responsible for anticipating and preventing conflicts, as well as for undertaking peace-making and peace-building functions. ${ }^{60}$ Accordingly, the AU Commission has selected the vast majority of envoys currently deployed by the organization - with the

59 In both cases, this configuration was preceded by a different type of double-hatting in which EusRs also held internationally mandated roles. See Mateja Peter, 'Double-hatting in EU External Engagements: EU Special Representatives and the Question of Coherence Post-Lisbon', swP Comments 2012/C 46 (December 2012).

6o See online at http://www.peaceau.org/uploads/psc-protocol-en.pdf. 
exception of the Special Envoy for Western Sahara, whose appointment was endorsed by the AU PSC.

The AU can deploy four categories of emissaries: (i) Special Envoys, representing the bigger share and country-based; (ii) High Representatives of the Chairperson, sometimes referred to as 'special envoys' as well, but not countrybased; (iii) Special Representatives of the Chairperson, normally based incountry with dedicated staff; and (iv) High-Level Ad-Hoc Committees, which, although not explicitly mentioned in the AU PSC Protocol, can be established as needed. More largely than in other multilateral organizations, it has become common practice for the AU to appoint high-profile envoys as mediators, including several eminent African political leaders who are perceived to carry considerable political weight. In parallel, the last decade has seen various subregional organizations in Africa (as well as in the Middle East) gradually assuming a more prominent role in addressing political crises. As crises became more complex, these bodies began to realize their unique position in conflict resolution and mediation, deriving from better access to, more knowledge of and leverage over conflicting parties.

For instance, the Inter-Governmental Authority on Development (IGAD) engaged with the conflicts in Somalia, Sudan and South Sudan through six special envoys. The Economic Commission of West African States (EcowAS) addressed recent crises in Ivory Coast, Guinea-Bissau and Mali by deploying a number of ad-hoc mediators. The Southern African Development Community (SADC) regularly picks special envoys tasked with mediation, conflict prevention and preventive diplomacy efforts, whose interventions have materialized in Lesotho, Zimbabwe, Madagascar and lately in the Democratic Republic of Congo. As for the Middle East region, the Gulf Cooperation Council (GCC) and the League of Arab States (LAS) have played noticeable mediation roles in Yemen and Syria through their special envoys. In particular, the deteriorating situation in Syria led to relaunching the formula of 'joint envoy' representing more than one institution. While this configuration adds a further dimension of versatility to the envoy's role, the delicate balance between political mandate and operational needs may often hamper effectiveness. Thus, this model has been used by multilateral actors only sparsely: in 2008, a Joint AUUN Special Representative and Joint Chief Mediator for Darfur; (ii) in 2012, a UN-LAS Joint Special Representative for Syria (discontinued in May 2014); and (iii) in 2009, a joint AU-SADC Envoy to Madagascar. 
TABLE 2 Comparative outlook on common geographical areas of activity of selected past and present special envoys/representatives

$\begin{array}{lllll}\text { Country/ } & \text { Major } & \text { UNSC } P_{5} & \text { Other actors } & \text { Format/ } \\ \text { region } & \text { international/ } & & \text { mechanism } \\ & \text { regional } & & \text { involving special } \\ & \text { erganizations } & & \\ & & & \text { represens and } \\ & & & \end{array}$

\begin{tabular}{|c|c|c|c|c|}
\hline $\begin{array}{l}\text { Afghanistan } \\
\text { (and } \\
\text { Pakistan) }\end{array}$ & $\begin{array}{l}\text { European } \\
\text { Union (EU), UN }\end{array}$ & $\begin{array}{l}\text { China, } \\
\text { France, } \\
\text { Russia, } \\
\text { UK, US }\end{array}$ & $\begin{array}{l}\text { Individual } \\
\text { members of } \\
\text { International } \\
\text { Contact Group }\end{array}$ & $\begin{array}{l}\text { International } \\
\text { Contact Group for } \\
\text { Afghanistan }\end{array}$ \\
\hline $\begin{array}{l}\text { African } \\
\text { Great Lakes }\end{array}$ & $\begin{array}{l}\text { African Union } \\
(\mathrm{AU}), \mathrm{EU}, \mathrm{UN}\end{array}$ & $\begin{array}{l}\text { France, } \\
\text { UK, US }\end{array}$ & $\begin{array}{l}\text { Belgium, } \\
\text { Netherlands, } \\
\text { Norway, } \\
\text { South Africa, } \\
\text { Sweden }\end{array}$ & $\begin{array}{l}\text { International } \\
\text { Contact Group for } \\
\text { the Great Lakes } \\
\text { region, Team of } \\
\text { International Special } \\
\text { Envoys }\end{array}$ \\
\hline $\begin{array}{l}\text { Middle } \\
\text { East Peace } \\
\text { Process }\end{array}$ & EU, UN & $\begin{array}{l}\text { China, } \\
\text { France, } \\
\text { Russia, } \\
\text { UK, US }\end{array}$ & $\begin{array}{l}\text { Japan, Norway, } \\
\text { Sweden }\end{array}$ & Middle East Quartet \\
\hline Libya & $\begin{array}{l}\text { AU, EU, UN, } \\
\text { League of Arab } \\
\text { States (LAS) }\end{array}$ & $\begin{array}{l}\text { France, } \\
\text { UK, US }\end{array}$ & $\begin{array}{l}\text { Germany, Italy, } \\
\text { Malta, Spain, } \\
\text { Turkey }\end{array}$ & $\begin{array}{l}\text { "Ambassadors and } \\
\text { Special Envoys" }\end{array}$ \\
\hline Sahel & AU, EU, UN & $\begin{array}{l}\text { France, } \\
\text { UK }\end{array}$ & $\begin{array}{l}\text { Economic } \\
\text { Commission of } \\
\text { West African } \\
\text { States (ECOWAs), } \\
\text { Italy, Organization } \\
\text { of Islamic } \\
\text { Cooperation (oIC), } \\
\text { Spain }\end{array}$ & $\begin{array}{l}\text { Algiers Process; } \\
\text { Nouakchott Process }\end{array}$ \\
\hline $\begin{array}{l}\text { Somalia/ } \\
\text { Horn of } \\
\text { Africa }\end{array}$ & AU, EU, UN & UK, US & $\begin{array}{l}\text { Finland, } \\
\text { Intergovernmental } \\
\text { Authority on } \\
\text { Development } \\
\text { (IGAD), Italy, } \\
\text { Sweden }\end{array}$ & $\begin{array}{l}\text { Djibouti Peace } \\
\text { Process }\end{array}$ \\
\hline
\end{tabular}


TABLE 2 Comparative outlook on common geographical areas of activity (cont.)

\begin{tabular}{|c|c|c|c|}
\hline $\begin{array}{l}\text { Country/ } \\
\text { region }\end{array}$ & $\begin{array}{l}\text { Major } \\
\text { international/ } \\
\text { regional } \\
\text { organizations }\end{array}$ & Unsc $\mathrm{P}_{5}$ Other actors & $\begin{array}{l}\text { Format/ } \\
\text { mechanism } \\
\text { involving special } \\
\text { envoys and } \\
\text { representatives }\end{array}$ \\
\hline
\end{tabular}

\begin{tabular}{|c|c|c|c|c|}
\hline $\begin{array}{l}\text { South } \\
\text { Caucasus }\end{array}$ & $\begin{array}{l}\text { EU, osce, UN, } \\
\text { NATO }\end{array}$ & $\begin{array}{l}\text { Russia, } \\
\text { UK, US }\end{array}$ & $\begin{array}{l}\text { Australia, } \\
\text { Germany, New } \\
\text { Zealand }\end{array}$ & $\begin{array}{l}\text { Geneva International } \\
\text { Discussions; os CE } \\
\text { Minsk Group }\end{array}$ \\
\hline $\begin{array}{l}\text { Sudan/ } \\
\text { Darfur and } \\
\text { South } \\
\text { Sudan }\end{array}$ & AU, EU, UN & $\begin{array}{l}\text { China, } \\
\text { France, } \\
\text { Russia, } \\
\text { UK, US }\end{array}$ & $\begin{array}{l}\text { Austria, Canada, } \\
\text { Finland, Germany, } \\
\text { IGAD, Italy, } \\
\text { Japan, Italy, LAS, } \\
\text { Netherlands, } \\
\text { Norway, Sweden, } \\
\text { South Africa }\end{array}$ & $\begin{array}{l}\text { Informal “Troika”; } \\
\text { Abuja Process; } \\
\text { Doha Talks; Joint } \\
\text { Commission on } \\
\text { Darfur; IGAD-Plus; } \\
\text { AU High-level } \\
\text { Implementation } \\
\text { Panel }\end{array}$ \\
\hline Syria & $\begin{array}{l}\text { EU, UN } \\
\text { (previously } \\
\text { with LAS) }\end{array}$ & $\begin{array}{l}\text { China, } \\
\text { France, } \\
\text { Russia, } \\
\text { UK, US }\end{array}$ & $\begin{array}{l}\text { Denmark, } \\
\text { Germany, } \\
\text { Netherlands, } \\
\text { Sweden }\end{array}$ & $\begin{array}{l}\text { Intra-Syrian Peace } \\
\text { Process; Astana } \\
\text { talks; Small Group of } \\
\text { countries }\end{array}$ \\
\hline
\end{tabular}

\section{Conclusion}

Special envoys embody the essence of diplomacy in its persisting tension between change and continuity. For centuries, this instrument has effectively addressed the challenges presented by a transforming international system that affected traditional diplomatic practices in manifold ways. Ad-hoc emissaries have hence gained relevance in relation to various dimensions of change in diplomacy. They can be swiftly deployed by state and non-state entities alike and tasked with short-term and long-term missions in an official and unofficial guise. Drawn from different milieus with generalist or specialist expertise, they can combine various functions or engage in specific tasks. Acting from their headquarters or in the field, they often operate alongside other players within lopsided or symmetrical interactions. Finally, they may contribute to 
an integrated approach across governmental structures or sister agencies and organizations. In this perspective, special envoys are pioneering agents of the 'integrative' model of diplomacy, functioning as coordinators, boundaryspanners or managers, as circumstances require. All key international players have grasped this phenomenon. A study of nearly $65^{\circ}$ past and present special envoys/representatives serving for major world powers and multilateral organizations indicates a steady rise in numbers over the last 25 years, accompanied by a greater focus on thematic/horizontal issues.

With regard to $\mathrm{P}_{5}$ country-mandated envoys, certain similarities and differences in administrative and diplomatic styles emerge. Governments continue to appoint special representatives in response to serious crises and to signal policy priorities or national interests. A majority of these envoys address conflict situations as mediators or observers, often under the umbrella of broader regional mandates to maximize political weight and visibility. In order to manage their overall engagement, most countries modulate the envoy's geographi$\mathrm{cal} /$ thematic scope of action and the mandate's timeframe upon short-term and longer-term objectives: at different points in time, almost no $\mathrm{P}_{5}$ country had more than fifteen special envoys simultaneously operational. The recently emerging 'economic/commercial diplomacy' component, ${ }^{61}$ however, altered this paradigm: presently, this category accounts for almost one-third of the total number of special envoys deployed by the $\mathrm{P}_{5}$.

The United States constitutes a notable exception: individual policy orientations of each administration have favoured an extraordinary proliferation of special emissaries of all sorts over the last decade. The State Department's initiative to cut several of these positions illustrates the potential risks associated with 'overstretching' the notion of special envoy, which may negatively impact perceptions of the function's usefulness and legitimacy. In the cases of France and the UK, special representatives are selected across a broad professional spectrum (diplomats, politicians, businessmen, sectoral and technical experts) to spearhead policy initiatives. Specialization and capacity to manage complex policy networks are key elements in the choice. Recognizing the diversity of issues dealt with at a diplomatic level, both France and the UK channel the support of multiple governmental departments towards their ministries of foreign affairs, occasionally opting for a 'joint envoy' formula. As for China and Russia, the existence of consolidated power structures strongly defines the authority carried by special representatives, as well as their operational capacity. Their mandates derive directly from the leadership and are carried out in close association with relevant ministries. In both countries, regular bureaucrats mainly

61 Hocking et al., 'Integrative Diplomacy in the 21st Century'. 
hold these functions and recurring examples exist of double-hatted positions with an ample geographical remit.

Overall, the different degrees of integration observed between the $\mathrm{P}_{5}$ special envoys and their respective foreign ministries show how this model can effectively serve specific purposes within diverse administrative cultures. As the relatively common cross-departmental cooperation demonstrates, envoys often constitute the interface between domestic and international policies, thereby addressing the need for adaptation of machineries and techniques in the broader national diplomatic system. More generally, the extensive use of national special envoys illustrates the capacity of sovereign states to turn diplomatic innovation to their advantage. Despite continuous systemic changes in the content and practice of diplomacy, ad-hoc emissaries embody state resilience and adaptivity to change in the international arena. ${ }^{62}$

For multilateral organizations, the key function of diplomacy remains to contribute to the peaceful settlement of disputes between states and/or other actors. Following in the footsteps of the first UN-mandated emissaries, the notion of special representative became inextricably linked to mediation. The enhanced emphasis on conflict prevention at the global level added a further dimension, catalysing other actors' interest in getting directly involved in the field. As the UN consolidated its practice of deploying special emissaries for emerging and protracted conflicts, several regional organizations followed suit and made analogous appointments. Currently, over half of the envoys deployed by major multilateral institutions work alongside each other in various conflict settings and diplomatic negotiation processes, predominantly with mediationrelated tasks. In keeping with the UN's efforts to work out partnerships with regional actors on both conflict management and mediation, complementarity was sought through innovative arrangements such as double-hatting, albeit applied moderately so far.

The increasing employment of special envoys by pivotal international players both contributes and responds to the 'inflation' of diplomatic service providers presently available. This represents a worldwide trend that became the norm in a widening multilateral, multipolar and multi-stakeholder context. This is particularly visible when looking at conflict situations around the world (see Table 2). In 2017, at least twenty envoys from major international powers and 32 from multilateral organizations operated in the same country, region or sub-region across four continents, with varying roles in crisis management, mediation or support to diplomatic processes.

62 Samy Cohen, The Resilience of the State: Democracy and the Challenge of Globalization (Boulder, CO: Lynne Rienner, 2003). 
While this comparative analysis has sought to expose the macro-level interrelations between the use of special envoys and the evolution of diplomatic practices, further research is needed to examine in more detail various related processes. Considerations on resource effectiveness, as well as on the trends of fragmentation and concentration within individual national diplomatic systems appear to be particularly relevant. ${ }^{63}$ Recent scholarly literature offers a useful analytical lens to investigate how and to what extent growing interdependences between ad-hoc envoys and their interlocutors, as well as the content of these interactions, continue to shape contemporary diplomacy. ${ }^{64}$

Francesco Morini is a Ph.D. candidate in European Studies at Maastricht University in the Netherlands, focusing his research on the changing patterns of diplomacy and the role of special envoys and representatives in this context. He is simultaneously a foreign policy professional who has been working for several years in the European institutions in Brussels.

63 Hocking et al., 'Integrative Diplomacy in the 21st Century', p. 55.

64 For example, Vincent Pouliot and Jérémie Cornut, 'Practice, Theory and the Study of Diplomacy: A Research Agenda', Cooperation and Conflict, vol. 50, no. 3 (2015), pp. 297-315; and Jan Melissen, 'Diplomatic Studies in the Right Season', International Studies Review, vol. 13, no. 4 (2011), pp. 723-725. 